\title{
The Effect of Seasonal Temperature Changes on Gestational Diabetes Mellitus Prevalence
}

\section{Mevsimsel Sıcaklık Değişikliklerinin Gestasyonel Diabetes Mellitus Prevalansı Üzerine Etkisi}

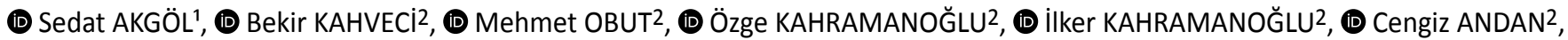 \\ (D) Mehmet Şükrü BUDAK3 \\ 1 University of Health Sciences Turkey, Kanuni Sultan Süleyman Training and Research Hospital, Clinic of Obstetrics and Gynecology, Istanbul, Turkey \\ ${ }^{2}$ Çukurova University Faculty of Medicine, Department of Obstetrics and Gynecology, Adana, Turkey \\ ${ }^{3}$ Dicle University Faculty of Medicine, Department of Obstetrics and Gynecology, Diyarbakır, Turkey
}

\begin{abstract}
Aim: The aim of this study was to investigate the effect of seasonal changes in ambient temperature on the prevalence of gestational diabetes mellitus (GDM).

Materials and Methods: A retrospective evaluation was performed on the results of patients at 24-28 weeks gestation who underwent a GDM screening at the University of Health Sciences Turkey, Gazi Yaşargil Training and Research Hospital in Diyarbakır, which is a city that is warm and dry in summer and cold and rainy in winter, between January 2017 and December 2017. Pregnant women were divided into four groups according to the season they were screened for GDM. A comparison was made in terms of the prevalence of GDM among pregnant women screened for diagnosis of GDM in different seasons.

Results: Of 3,618 pregnant women screened, 7.5\% ( $n=272)$ were diagnosed with GDM. The seasonal distribution of the GDM cases was 6.4\% ( $n=54)$ in winter, $8.3 \%(n=78)$ in spring, 9.2\% $(n=84)$ in summer, and $6.1 \%(n=56)$ in autumn. A significant difference was observed in terms of seasonal distribution $(\mathrm{p}<0.05)$.

Conclusion: The results of this study have demonstrated that seasonal temperature changes have a significant effect on GDM prevalence. However, further studies are needed to better demonstrate this relationship.
\end{abstract}

Keywords: Gestational diabetes mellitus, seasonal temperature, prevalence

ÖZ

Amaç: Bu çalışmada, ortam sıcaklığındaki mevsimsel değişikliklerin gestasyonel diabetes mellitus (GDM) prevalansı üzerine etkisinin araştırılması amaçlanmıştır.

Gereç ve Yöntem: Ocak 2017-Aralık 2017 tarihleri arasında, yazları sıcak ve kurak, kışın soğuk ve yağışlı bir şehir olan Diyarbakır'da Sağlık Bilimleri Üniversitesi, Gazi Yaşargil Eğitim ve Araştırma Hastanesi'nde GDM taraması yapılan 24.-28. haftalarında olan gebelerin sonuçları retrospektif olarak değerlendirildi. GDM taraması yapılan hamile kadınlar mevsimlere göre dört gruba ayrıldı. Farklı mevsimlerde GDM tanısı konulan gebelerde GDM prevalansı açısından bir karşılaştırma yapıldı.

Bulgular: Taranan 3.618 gebe arasından \%7,5'i (n=272) GDM tanısı aldı. GDM olgularının mevsimsel dağılımı kışın \%6,4 (n=54), ilkbaharda \%8,3 $(n=78)$, yaz aylarında \%9,2 ( $n=84)$ ve sonbaharda \%6,1 $(n=56)$ olmuştur. Mevsimsel dağılım açısından anlamlı bir fark gözlendi $(p<0,05)$.

Sonuç: Bu çalışmanın sonuçları, mevsimsel sıcaklık değişimlerinin GDM prevalansı üzerinde anlamlı bir etkisi olduğunu göstermiştir. Ancak, bu ilişkiyi daha iyi göstermek için daha fazla çalışmaya ihtiyaç vardır.

Anahtar Kelimeler: Gestasyonel diabetes mellitus, mevsimsel sıcaklık, prevalans

Address for Correspondence: Bekir KAHVECI MD, Çukurova University Faculty of Medicine, Department of Obstetrics and Gynecology, Adana, Turkey Phone: +90 5064186628 E-mail: drbekirkahveci@ hotmail.com ORCID ID: orcid.org/0000-0002-8729-1669

Received: 31.07.2019 Accepted: 09.02.2020

${ }^{\circ}$ Copyright 2021 by the Tekirdağ Namık Kemal University Faculty of Medicine / Namık Kemal Medical Journal published by Galenos Publishing House. 


\section{INTRODUCTION}

Gestational diabetes mellitus (GDM) is defined as glucose intolerance of varying degrees beginning during pregnancy or first diagnosed during pregnancy ${ }^{1,2}$. It affects approximately $7 \%$ of pregnancies, and varies widely between $2.4 \%$ and $21 \% 0^{3-}$

5 . Despite a clinically asymptomatic evolution, there is an increased risk of type 2 diabetes (T2D) mellitus in the long term as well as increased pregnancy and delivery complication $\mathrm{s}^{6-8}$.

Despite the increase in GDM frequency over the years, the pathophysiology is still not fully understood ${ }^{9,10}$. Nevertheless, risk factors such as maternal overweight and obesity, low maternal birth weight, race, increased maternal age, family history of T2D, fetal death history, a macrosomic infant history, high saturated fat consumption, high ambient temperature and low $\mathrm{D}$ vitamin level have been revealed ${ }^{11-13}$.

Brown fat tissue has an irreplaceable role in assisting the body to adapt to cold weather by producing adenosine triphosphate via the cellular mitochondrial system ${ }^{14,15}$. Based on evidence from animal and human studies, it has been shown that brown fat tissue is effective in body thermogenesis by altering the whole body's metabolism ${ }^{16,17}$. In some animal experiments, the reduction of the thermostat temperature from $24{ }^{\circ} \mathrm{C}$ to $19{ }^{\circ} \mathrm{C}$ resulted in a $30-40 \%$ increase of activity in brown fat and an increase in insulin sensitivity ${ }^{17-19}$. GDM is a metabolic disease, characterized by changes in the glucose and lipid metabolism as a result of insulin resistance ${ }^{20}$. Environmental temperature, which has been shown to cause changes in insulin resistance, has increased globally over the past century and this has also raised concerns related to human health ${ }^{17,21,22}$. From a review of literature, it can be seen that very few studies have examined the seasonal variation of the prevalence of GDM, due to seasonal changes in ambient temperature during the year and the effects of these changes on insulin sensitivity ${ }^{10,23-26}$.

The aim of this study was to investigate the effect of seasonal temperature variations on GDM prevalence.

\section{MATERIALS AND METHODS}

The study were approved by the Ankara Numune Training and Research Hospital of Local Ethics Committee (protocol number: E-19-2669, date: 18.04.2019). The study included patients with one-step GDM result in a $75 \mathrm{~g}$ oral glucose tolerance test (OGTT) or a two-step GDM result in a $100 \mathrm{~g}$ OGT following a $50 \mathrm{~g}$ oral glucose challenge test (OGCT) applied to pregnant women at 24-28 weeks, as defined by the last menstrual period and the first trimester obstetric ultrasound in the University of Health Sciences Turkey, Gazi Yaşargil Training and Research Hospital in Diyarbakır, between January 1, 2017 and December 31, 2017. This city has a climate that is warm and dry in summer and cold and rainy in winter. The GDM screening results of these pregnant women were evaluated retrospectively through the hospital automation system. GDM diagnosis was established when one or more of the three blood sugar values (fasting: $\geq 92$ $\mathrm{mg} / \mathrm{dL}, 1^{\text {st }}$ hour $\geq 180 \mathrm{mg} / \mathrm{dL}$ and $2^{\text {nd }}$ hour $\geq 153 \mathrm{mg} / \mathrm{dL}$ ) screened in a single step scan with $75 \mathrm{~g}$ OGT were high ${ }^{27}$. In the two-step scan, 24-28-week pregnant women with a 1-hour blood sugar level lower than $140 \mathrm{mg} / \mathrm{dL}$ following a $50 \mathrm{~g}$ OGCT were considered normal, while pregnant women with a 1-hour blood sugar level between 140 and $199 \mathrm{mg} / \mathrm{dL}$ were subjected to a $100 \mathrm{~g} \mathrm{OGT}$. For the patients subjected to $100 \mathrm{~g}$ OGT, according to the Carpenter-Coustan Conversion criteria, GDM diagnosis was established when two or more of the four blood sugar values (Fasting blood glucose: 95 $\mathrm{mg} / \mathrm{dL}, 1^{\text {st }}$ hour $180 \mathrm{mg} / \mathrm{dL}, 2^{\text {nd }}$ hour $155 \mathrm{mg} / \mathrm{dL}$ and $3^{\text {rd }}$ hour $140 \mathrm{mg} / \mathrm{dL}$ ) were high after $100 \mathrm{~g} \mathrm{OGT}$ and $1^{\text {st }}$ hour blood sugar value after a $500 \mathrm{GCT}$ was $200 \mathrm{mg} / \mathrm{dL}$ or more $\mathrm{e}^{27,28}$. The seasons were determined by calendar (winter; DecemberJanuary-February, spring; March-April-May, summer; JuneJuly-August, autumn; September-October-November). The seasonal temperature values of the province of Diyarbakır in 2017 were obtained from the link of the temperature analysis given on the website of the General Directorate of Meteorology of the Ministry of Forestry and Water Affairs of the Republic of Turkey ${ }^{29}$. A comparison was made in terms of mean age, mean gravida and GDM prevalence among pregnant women screened for the diagnosis of GDM in the different seasons.

\section{Statistical Analysis}

Descriptive statistics (mean, standard deviation, frequency, percentage) were used to define continuous variables. The chi-square test was used to examine the relationship between categorical variables. A value of $p<0.05$ was accepted as statistically significant. The analyses were performed using the MedCalc Statistical Software version 12.7.7 (MedCalc Software bvba, Ostend, Belgium; http://www.medcalc.org).

\section{RESULTS}

The study included 3,618 pregnant women subjected to GDM screening at 24-28 gestational weeks between January 1, 2017 and December 31, 2017. Of these, 1358 (37.53\%) were scanned with $75 \mathrm{~g} \mathrm{OGT,} \mathrm{as} \mathrm{a} \mathrm{single-step} \mathrm{scan,} \mathrm{and} \mathrm{2,262} \mathrm{(62.52 \% )} \mathrm{were}$ scanned using a two-step scan with $50 \mathrm{~g}$ OGCT, followed by $100 \mathrm{~g} \mathrm{OGT}$. As a result of the two screening models, the overall rate of cases diagnosed as GDM was 7.5\% $(n=272)$, with the following distribution: $6.4 \%(n=54)$ in winter, $8.3 \%(n=78)$ in spring, 9.2\% $(n=84)$ in summer and $6.1 \%(n=56)$ in autumn. The seasonal average temperatures were $3.6^{\circ} \mathrm{C}$ in winter, 13.5 ${ }^{\circ} \mathrm{C}$ in spring, $27.9{ }^{\circ} \mathrm{C}$ in summer and $17.4^{\circ} \mathrm{C}$ in autumn (Figure 1). The mean age, gravida, average temperatures and GDM 
prevalence according to seasons are shown in Table 1. There were no statistically significant differences in the mean age and mean gravida of pregnant women who were screened for the diagnosis of GDM in different seasons (Table 1). There was a statistically significant difference in the prevalence of GDM in pregnant women who were screened for the diagnosis of GDM in different seasons (Table 1).

\section{DISCUSSION}

The results of this study showed that the prevalence of GDM was seasonally different and this difference was found to be statistically significant. While Booth et al. ${ }^{22}$, Chiefari et al. ${ }^{23}$ and Vasileiou et al. ${ }^{26}$ found results similar to those of the current study, Moses et al. ${ }^{24}$ reported no significant difference in the seasonal distribution of GDM prevalence. However, the study of Moses et al. ${ }^{24}$ was conducted in Wollongong, Australia, where the average temperature difference between the warmest and coldest seasons is $9.3^{\circ} \mathrm{C}^{30}$. In the current study, this difference is $24.3^{\circ} \mathrm{C}$. In the study by Booth et al..$^{22}$, which showed a significant difference between seasonal frequencies

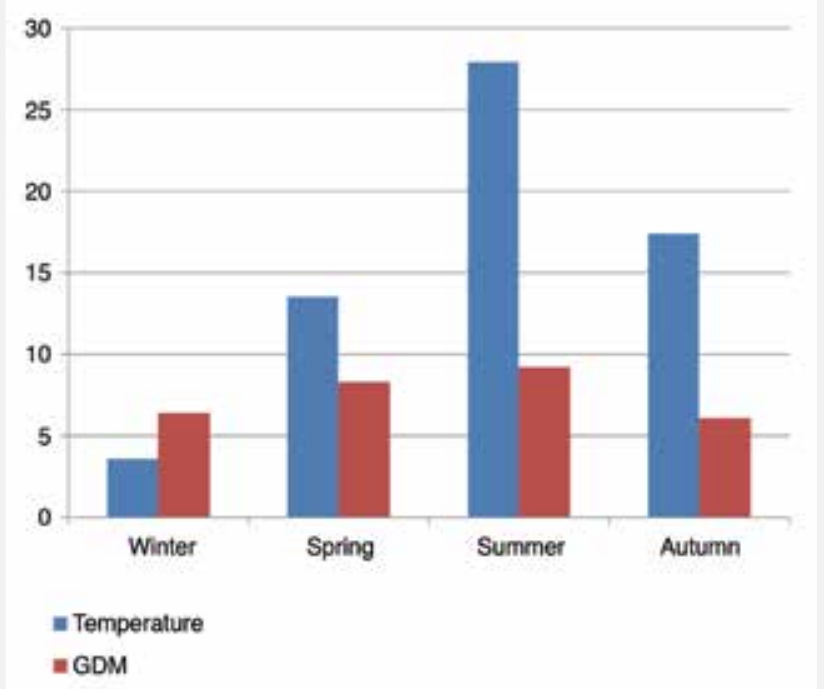

Figure 1. The distribution of seasonal temperature averages and gestational diabetes mellitus rates

GDM: Gestational diabetes mellitus of GDM prevalence similar to the current study, the average temperature difference between the coldest and warmest seasons was $24.13{ }^{\circ} \mathrm{C}$, whereas it was $13.5^{\circ} \mathrm{C}$ in the study of Chiefari et al. ${ }^{23}$. It can therefore be suggested that the result found by Moses et al. ${ }^{24}$ for seasonal variation in the prevalence of GDM is different from the results of the current study and previous research ${ }^{22,23}$ because of this low temperature difference between the coldest and warmest seasons ${ }^{22,23,29}$.

In the current study, the GDM prevalence increased with increasing temperature and reached the highest value in the summer. Other recent studies have also reported that the GDM prevalence increases with temperature and the highest prevalence is seen in summer ${ }^{22-24}$. Booth et al. ${ }^{22}$ reported the rate of increase in GDM frequency as a 6-9\% increase in the risk of the development of GDM for every $10{ }^{\circ} \mathrm{C}$ temperature increase. It has been shown in several studies that a decrease in temperature is accompanied by an increase in brown fat tissue activity for thermoregulation and this is associated with an increase in insulin sensitivity ${ }^{17}$. In the current study, the increase in GDM prevalence with the increase in temperature may be related to increased insulin resistance as a result of reduced insulin sensitivity, related to the increase in temperature, which is known to have an effect on insulin sensitivity and because insulin resistance has an important place in GDM pathophysiology ${ }^{20}$.

\section{Study Limitations}

The main limitation of this study is its retrospective design. However, the large sample can be considered to render the results of value.

\section{CONCLUSION}

Seasonal temperature changes were found to have a statistically significant effect on GDM prevalence. Therefore, women at increased risk of GDM should consider the effect of seasonal temperature increases on the prevalence of GDM when they plan a pregnancy. In particular, it should be attempted to avoid the summer months coinciding with the second trimester of the pregnancy. However, further studies are needed to better demonstrate this relationship.

Table 1. Seasonal distribution of gestational diabetes mellitus pregnancies

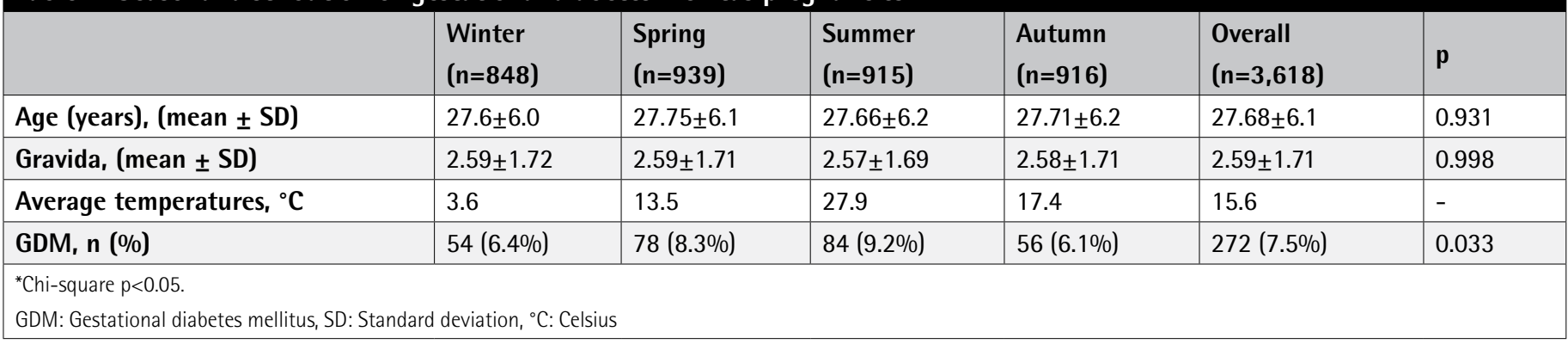




\section{Ethics}

Ethics Committee Approval: The study were approved by the Ankara Numune Training and Research Hospital of Local Ethics Committee (protocol number: E-19-2669, date: 18.04.2019).

\section{Informed Consent: Retrospective study.}

Peer-review: Externally peer-reviewed.

\section{Authorship Contributions}

Surgical and Medical Practices: S.A., B.K., M.O., Ö.K., I.K., C.A., M.Ş.B., Concept: B.K., M.Ş.B., Design: B.K., M.Ş.B., Data Collection or Processing: S.A., M.O., C.A., Analysis or Interpretation: B.K., M.Ş.B., Literature Search: S.A., Ö.K., I.K., Writing: B.K., M.Ş.B.

Conflict of Interest: No conflict of interest was declared by the authors.

Financial Disclosure: The authors declared that this study received no financial support.

\section{References}

1. Wilmot EG, Mansell P. Diabetes and pregnancy. Clin Med (Lond). 2014;14:677-80.

2. McIntyre HD. Discovery, Knowledge, and Action-Diabetes in Pregnancy Across the Translational Spectrum: The 2016 Norbert Freinkel Award Lecture. Diabetes Care. 2018;41:227-32.

3. Budak MS, Kahramanoglu I, Vitale SG, Akgol S, Dilek ME, Kartal S, et al. Maternal abdominal subcutaneous fat thickness as a simple predictor for gestational diabetes mellitus. J Perinat Med. 2019;47:605-10.

4. Budak MŞ, Araç E. Maternal hypoglycaemia on the $50 \mathrm{~g}$ oral glucose challenge test - evaluation of obstetric and neonatal outcomes. Ginekol Pol. 2018;89:370-4.

5. American Diabetes Association. Diagnosis and classification of diabetes mellitus. Diabetes Care. 2014;37:81-90.

6. Crowther CA, Hiller JE, Moss JR, McPhee AJ, Jeffries WS, Robinson JS, et al. Effect of treatment of gestational diabetes mellitus on pregnancy outcomes. N Engl J Med. 2005;352:2477-86.

7. HAPO Study Cooperative Research Group, Metzger BE, Lowe LP, Dyer AR, Trimble ER, Chaovarindr U, et al. Hyperglycemia and adverse pregnancy outcomes. N Engl J Med. 2008;358:1991-2002.

8. Rayanagoudar G, Hashi AA, Zamora J, Khan KS, Hitman GA, Thangaratinam S. Quantification of the type 2 diabetes risk in women with gestational diabetes: a systematic review and meta-analysis of 95,750 women. Diabetologia. 2016;59:1403-11.

9. Getahun D, Nath C, Ananth CV, Chavez MR, Smulian JC. Gestational diabetes in the United States: temporal trends 1989 through 2004. Am J Obstet Gynecol. 2008;198:525.

10. Verburg PE, Tucker G, Scheil W, Erwich JJ, Dekker GA, Roberts CT. Seasonality of gestational diabetes mellitus: a South Australian population study. BMJ Open Diabetes Res Care. 2016;4:000286.

11. Ben-Haroush A, Yogev $Y$, Hod M. Epidemiology of gestational diabetes mellitus and its association with Type 2 diabetes. Diabet Med. 2004;21:10313.
12. Schmidt MI, Mengue SS, Duncan BB, Branchtein L, Matos MC, Reichelt AJ, et al. Variation in glucose tolerance with ambient temperature. Lancet. 1994;344:1054-5.

13. Akanji AO, Bruce M, Frayn K, Hockaday TD, Kaddaha GM. Oral glucose tolerance and ambient temperature in non-diabetic subjects. Diabetologia. 1987;30:431-3.

14. Betz MJ, Enerbäck S. Human Brown Adipose Tissue: What We Have Learned So Far. Diabetes. 2015;64:2352-60.

15. Celi FS, Brychta RJ, Linderman JD, Butler PW, Alberobello AT, Smith S, et al. Minimal changes in environmental temperature result in a significant increase in energy expenditure and changes in the hormonal homeostasis in healthy adults. Eur J Endocrinol. 2010;163:863-72.

16. van der Lans AA, Hoeks J, Brans B, Vijgen GH, Visser MG, Vosselman MJ, et al. Cold acclimation recruits human brown fat and increases nonshivering thermogenesis. J Clin Invest. 2013;123:3395-403.

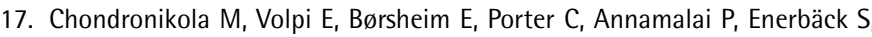
et al. Brown adipose tissue improves whole-body glucose homeostasis and insulin sensitivity in humans. Diabetes. 2014;63:4089-99.

18. Hanssen MJ, Hoeks J, Brans B, van der Lans AA, Schaart G, van den Driessche $\mathrm{JJ}$, et al. Short-term cold acclimation improves insulin sensitivity in patients with type 2 diabetes mellitus. Nat Med. 2015;21:863-5.

19. Tumurbaatar B, Poole AT, Olson G, Makhlouf M, Sallam HS, Thukuntla S, et al. Adipose Tissue Insulin Resistance in Gestational Diabetes. Metab Syndr Relat Disord. 2017;15:86-92.

20. Haines A, Patz JA. Health effects of climate change. JAMA. 2004;291:99103.

21. Virtanen KA, Lidell ME, Orava J, Heglind $M$, Westergren $R$, Niemi $T$, et al. Functional brown adipose tissue in healthy adults. $\mathrm{N} \mathrm{Engl} \mathrm{J} \mathrm{Med.}$ 2009;360:1518-25.

22. Booth GL, Luo J, Park AL, Feig DS, Moineddin R, Ray JG. Influence of environmental temperature on risk of gestational diabetes. CMAJ. 2017;189:682-9.

23. Chiefari E, Pastore I, Puccio L, Caroleo P, Oliverio R, Vero A, et al. Impact of Seasonality on Gestational Diabetes Mellitus. Endocr Metab Immune Disord Drug Targets. 2017;17:246-52.

24. Moses RG, Wong VC, Lambert K, Morris GJ, San Gil F. Seasonal Changes in the Prevalence of Gestational Diabetes Mellitus. Diabetes Care. 2016;39:121821.

25. Katsarou A, Claesson R, Ignell C, Shaat N, Berntorp K. Seasonal Pattern in the Diagnosis of Gestational Diabetes Mellitus in Southern Sweden. J Diabetes Res. 2016;2016:8905474.

26. Vasileiou V, Kyratzoglou E, Paschou SA, Kyprianou M, Anastasiou E. The impact of environmental temperature on the diagnosis of gestational diabetes mellitus. Eur J Endocrinol. 2018;178:209-14.

27. Canadian Diabetes Association Clinical Practice Guidelines Expert Committee, Thompson D, Berger H, Feig D, Gagnon R, Kader T, et al. Diabetes and pregnancy. Can J Diabetes. 2013;37:168-83.

28. Carpenter MW, Coustan DR. Criteria for screening tests for gestational diabetes. Am J Obstet Gynecol. 1982;144:768-73.

29. General Directorate of Meteorology of the Ministry of Forestry and Water Affairs of the Republic of Turkey. Accessed date: 18 January 2019. Available from: https://www.mgm.gov.tr/veridegerlendirme/sicaklik-analizi.aspx

30. Avarege temperature of Diyarbakır, Toronto, Catanzaro and Wollongong City. Accessed date: 18 January 2019. Available from: https://en.climatedata.org 